University of Wollongong

Research Online

Faculty of Law, Humanities and the Arts Papers (Archive)

Faculty of Arts, Social Sciences \& Humanities

$1-1-2013$

Desirable or dysfunctional? Family in recent Indian english-language fiction

Paul Sharrad

University of Wollongong, psharrad@uow.edu.au

Follow this and additional works at: https://ro.uow.edu.au/lhapapers

Part of the Arts and Humanities Commons, and the Law Commons

Research Online is the open access institutional repository for the University of Wollongong. For further information contact the UOW Library: research-pubs@uow.edu.au 


\title{
Desirable or dysfunctional? Family in recent Indian english-language fiction
}

\begin{abstract}
Meenakshi Mukherjee, in the period when Commonwealth Literature was attempting to establish the difference of national cultures from a British canon, pointed to the perception of early Indian novelists that South Asian family structures mitigated against working in a form based around individual characters (7-9). Where arranged marriage, the greater importance of the extended family unit, and caste affiliations had more social force, stories and their resolutions would have to look different from those of Hardy, Eliot or Henry James. If we think of the world of Austen, this is evidently a difference of degree rather than an absolute distinction, but Sudhir Kakar has also elaborated on the strength of ties in India between child and parent that moderate teenage rebellion and the radical break of adult individuation that the West has come to see as normal. The stress of Commonwealth Literature and its variants, on cultural specificity and local aesthetics, matched at the local end of the critical scale by nationalistic insistence on authenticity and tradition, kept literary treatments of the Indian family more or less centre stage but also perhaps under-examined in that they took for granted the general social grounding of particular fictions.
\end{abstract}

\section{Keywords}

era2015

Disciplines

Arts and Humanities | Law

\section{Publication Details}

Sharrad, P. (2013). Desirable or dysfunctional? Family in recent Indian english-language fiction. South Asia, 36 (1), 123-133. 


\section{Desirable or Dysfunctional? Family in recent Indian English Fiction}

\section{PAUL SHARRAD University of Wollongong}

Meenakshi Mukherjee, in the period when Commonwealth Literature was attempting to establish the difference of national cultures from a British canon, pointed to the perception of early Indian novelists that South Asian family structures mitigated against working in a form based around individual characters (7-9). Where arranged marriage, the greater importance of the extended family unit, and caste affiliations had more social force, stories and their resolutions would have to look different from those of Hardy, Eliot or Henry James. If we think of the world of Austen, this is evidently a difference of degree rather than an absolute distinction, but Sudhir Kakar has also elaborated on the strength of ties in India between child and parent that moderate teenage rebellion and the radical break of adult individuation that the West has come to see as normal. The stress of Commonwealth Literature and its variants, on cultural specificity and local aesthetics, matched at the local end of the critical scale by nationalistic insistence on authenticity and tradition, kept literary treatments of the Indian family more or less centre stage but also perhaps under-examined in that they took for granted the general social grounding of particular fictions.

In recent times, however, we find what appears to be a major shift in outlook. The White Tiger, to take the most striking example, shows the rise of a new kind of entrepreneur, breaking caste and class bounds through acts of violence that include the sacrifice of almost his entire family. Its protagonist Balram is the modern individual par excellence, and for all his extreme facets, is perhaps indicative of a new move away from the family-based novels of the past. Critics might well argue that Adiga is an expatriate freshly returned to his homeland and therefore constitutes 
an exceptional case. However, if we look around, it is evident that the Indian English novel reflects a significant change of outlook when it comes to family life and depictions of how it socialises its members. Vikram Chandra's "Kama" depicts the emotional complexities of divorce and swinging couples in Love and Longing in Bombay, Arundhati Roy reveals the viciously dysfunctional claustrophobia of family life in a minority community in The God of Small Things; there is incest at the heart of a number of recent novels (Raj Kamal Kha's The Blue Bedspread, Akhil Sharma's An Obedient Father), extra-marital affairs abound (Ammu's transgressive affair with low-caste Velu in The God of Small Things is merely a dramatic highlight in a range of books including Nilita Vachani's HomeSpun, Manju Kapur's Difficult Daughters, Namita Gokhale's The Book of Shadows, going back to Anita Desai's Fire on the Mountain).

Conservative critics no doubt fulminate against this trend, seeing it as symptomatic of the decline in morality, loss of nationalist ideals enshrined in Gandhi's principles of selfless service, godless Western influence, and so on. However, as the early criticism of 'feminist' writing shows, this has been a complaint levelled at anyone daring to write about things that orthodoxy hypocritically will not discuss: female dissatisfaction within marriage, for example. Subaltern historians and novels such as Difficult Daughters, HomeSpun and even the tame humour of R.K. Narayan also reveal that a good deal of obfuscation, self-delusion and moral failing was in play amongst individuals supporting the Gandhian movement, just as films like Rang de Basanti show the cynical perversion of those principles in more recent times by people in power. In all of these works, however, the stage on which conflicts of communities, history, gender interests and morality are enacted is the family. And in 
so far as the novel remains linked to realist depictions of society and human existence, it continues to set cultural ideals against actual engagements with them shaped by social movements nationally and globally.

Perhaps we could set up alongside the old critical models of Indian fiction that partition bhasa (vernacular) and Anglophone, desi (local) and diasporic, with another in which novels conveying continuity between individual, family, clan and nation are distinguished from those in which the seams of such a social cloth stretch and split. Like other binaries, this one is an untidy one allowing some cross-over, but it comes down a contrast between work on one hand in which the family remains a primary vehicle for socialisation and finding identity and work on the other for which family is a prison, something obsolete, or, more significantly, an irrelevance. The division is not an historical one: some of the earliest work in Indian fiction protests against the failings of arranged marriage, restrictions around widowhood and sati (Lokugé). Equally, modern urban novels, whether locally produced or written by expatriate Indians, can still centre on the family as the site of all being (a work such as Manju Kapur's Home, for example, or Amulya Malladi’s Serving Crazy with Curry), even when those families encompass divorce, suicide attempts, unhappy marriages and affairs.

That said, it must be admitted that certain modernising trends in society have a direct correlation with those novels in which family is no longer central to people's formation. Education can be a contradictory element in shaping family members. Obviously it played a major role in building the intelligentsia and merchant classes on which the management of independent India rests. We can clearly see the mutually 
sustaining connection of family and politics in the Nehru/Gandhi dynasty, even when (especially when) a member of it like Nayantara Sahgal writes novels critiquing its power. But educating one's children to improve a family's social prospects can also lead to their alienation from the family, and to restructuring of the family. When the elites of India began sending their sons to colleges to advance their prospects, the colleges started boarding facilities in part because young men were often married by the time they reached senior school and lived in busy extended families and could not concentrate on their reading (Baker 73) We can see this reflected in the out-of-kilter life of Jagan in Narayan's The Vendor of Sweets, in which his education is disrupted by his student activism against the Raj, his family marries him off to settle him down, and he fails to gain his university degree because he is too distracted by connubial delights and family quarrels when his wife does not immediately conceive.

Jagan gives up and becomes a shop owner, whereas others went to college, acquired degrees, entered professions, demanded educated wives who could mix openly in society and participate in social reform (as in Prem Chand's story "From both sides"), and so set in train a number of social changes to family life. Educated families curbed the number of children they had so they could afford to give them the same level of schooling, educated girls did not have to pay the large dowries demanded of other families, the age of marriage for educated women rose (Gupta \& Singh 152), and so the cycle perpetuated itself to the point that families wanting to appear modern and liberal could show off by not demanding a dowry at all, while young educated people, increasingly mixing on co-educational campuses, and spreading across the country then overseas as they found work, could push for the right to choose their own partners. 
This process is reflected in Gurcharan Das's conventional saga, A Fine Family, in which a senior Judge has to persuade his daughter Tara to accept an arranged marriage rather than pursue an infatuation with her cousin (61-2). Her father wryly notes that as soon as the young man's outgoing and outspoken nature leads him to jail as an independence fighter, his stakes in the marriage market fall, though his stocks with romantic girls go up: "You admire heroes from a distance thought Bauji; you don't marry your daughters to them" (83). Accordingly, he finds a safer option for his own daughter (87-8). The book seems to support the idea of the arranged marriage as more stable and superior to the modern love match, and though we see Tara becoming rather brittle and materialistic in reaction against her husband's non-worldliness, they do manage moments of tenderness, especially when united in the beauty of Simla's natural settling. Her husband, Seva Ram, though sharing a Punjabi male view of women as naturally weak and flighty (the author's words), admires his wife for her education and she in turn appreciates his earnest idealism (145-9). Her education complements her husband's rise through the civil service, and they eventually move to Delhi post-Independence. Tara's education comes back into focus when, as an enthusiastic supporter of Nehru's modernisation, she celebrates the passing of a bill allowing divorce and remarriage, abolishing dowry and requiring equal distribution of property amongst sons and daughters. Although he has raised her in principles of equity, her father is hurt that she protests when he attempts to give more of the family wealth to her brother (168-70).

As the title of the book suggests, family supplies a strong binding support, backed up by education. Cousin Karan becomes the beloved uncle of Tara's son, Arjun, 
instructing him in all kinds of things. Karan has given up his politics for scholarly and artistic pursuits, including reading the Upanishads and giving sitar recitals. Arjun goes to a Jesuit school and is the typical offspring of an upwardly mobile intelligentsia. His mother, like a good citizen of the new national elite, wants him to go on to

a fine college in Delhi like St Stephens, where he would acquire the necessary intellectual equipment, but not necessarily become a scholar. Then he would be ready to join the civil service or one of the professions, or industry or any of the pleasant niches for which the post-Independence Indian bourgeoisie groomed its young. After Arjun was settled she would marry him to a good Punjabi girl with the same background and education... And she hoped he would want to repeat the same process with his children. It was important to her that he should have more money than they did, so he would be able to send his children to boarding schools like Mayo or Doon, and if possible to a good university aborad, such as the Ivy League colleges in America or Oxford and Cambridge in England. This was Tara's recipe for an enviably happy life. $(217-18)$

His father is less inclined to accept such a materialist vision, and deplores Arjun's contact with the socialite Mehta family who "drink, ... smoke [and] eat meat" (219). His grandfather is more of an indulgent sensualist, disinclined to withdraw from the world, even though he is now seventy. But he too worries that Arjun will be hurt by Priti, the femme fatale Mehta daughter who leads the young man on, but also has a crush on the charismatic Karan. With his mother's emotional drive, his father's principled patience, and his Jesuit training, Arjun eventually becomes a successful 
salesman for a Bombay pharmaceutical company. There he eventually meets up with Priti coming to look for a job. They decide to marry (and their daughters do go to a boarding school).

Those daughters, however, are unlikely to produce the same kind of story as the older generations in A Fine Family. Arjun and Priti live in a Bombay that is depicted as a positive energy source for progress and freedom (345). India's rate of urbanisation suggests that this is a widespread view, and although the mega-cities have since provoked less positive representations (such as Vikram Chandra's or Vikas Swarup's depictions of the gangland violence that goes along with the real estate and IT boom and the movie industry) and begun to tail off in growth, other cities are still pulling in the youth from rural areas wanting to improve their prospects and young educated men and women chasing start-up industries and cheaper accommodation (Bhagat, Chauhan). Rohinton Mistry shows us (somewhat gloomily in A Fine Balance) how in the metropolis families can close themselves off against the world and also how people can create new modes of family to provide mutual support. But if Arjun and Priti's children join this general push to the big cities, their socialisation is more likely to depend on their 'batch mates' in school and college, and if they become the yuppie urbanites now consuming books like Chetan Bhagat's One night @ the call centre, they will rely more on their fellow professionals for solace, advice and potential partners than on their families. (Bhagat's call-centre gang still reproduce some of the socialisation patterns of old, particularly daughters warring with emotional blackmail from mothers wanting to marry them off or with domineering mothers-in-law, but the result is that those daughters break free with the support of their peers.) 
Karan Bajaj's Keep off the Grass can be taken as a fair sample of the world of such a 'facebook' generation. In a seemingly autobiographical picaresque philosophical comedy of stereotypic characters and situations, Samrat leaves his successful career on Wall Street and his American upbringing to seek his fortune in India. He joins the Indian Institute of Management in Bangalore to get an MBA, is blown away by the competitive culture of the higher education system, and hangs out with the cynical son of a Minister and an ex-soldier burnt out after fighting in Kargil. They drink and smoke dope through their course, swapping superficial philosophies until the inevitable police bust, the predictable trip to an ashram, and Samrat finding satisfaction in selling toiletries to Varanasi traders. He goes back to take a course on Indian society and learns some of the things that make him tick, including the importance of the family and social connections (179). At the same time, Samrat studiously avoids making contact with this relations in India, declines to go back to his family in the States, and in the most successful moment of the book, goes on a pilgrimage to the mountains to find wisdom at the feet of — Ruskin Bond! (255). We learn we must be who we are, belong where we feel we need to be and other such profundities. Samrat does discover his 'roots', but only through reading. Indian writing at first seems pretentious and unreal, but Narayan and English, August speak to him. Bond as a foreign resident offers him a model for anchoring his diasporic self. Rejecting the heady but alienating heights of the globalised corporate world, Samrat resolves to settle for a 'middle-brow' straightforwardness where no one in the diasporic world will ask him when he is going back home, no one will mispronounce his name or oblige him to read "confused immigrant fiction... about how much the author understood my dislocation in the US" (257). It's book to feel good about being 
Indian in which family seems not to feature, but the pulling together of alternative means of socialisation, the construction of a personalised 'family' is the key.

In such an atomised, urban, consumerist and corporate world, if one's marriage is unsatisfactory and one's social set too caught up in its own hip-ness, one might turn for help to the personal help industry of psychologists. Anupa Mehta's The Waiting Room is perhaps indicative of the new middle-class professional world's experience. It centres on a cross section of unhappy women who go to a psychologist for counselling and fall into a trap of sexual abuse. One of them, Maya Roy, conducts a series of interviews with fellow victims and writes her diaries as a means of working through her emotional trauma, complicated by her estranged husband's suspected abuse of their daughter. Beneath her determined journalistic objectification of her abuse, Maya is a troubled soul, and this finds an outlet in successive affairs coloured by 'new age' spiritual hunger, first in the form of tantric practices and then in a more sublime access to Sufism. After her death (of a broken heart, or, as the text puts it, "acute melancholia" and a body worn out by her quest for serenity), Maya's story is pieced together from documents by her long-time admirer from a distance, Aniket (Ket) Nair. Ket not only conserves her memory; he ends up the legal heir to custody of her child.

The book would be voyeuristic and pornographic if it were not written so clinically and with an air of personal therapy about it. Formula devices such as insistent adjectives and brand names with each noun are offset by the evident seriousness behind the story and the apt reproductions of different speech patterns from yuppie women, post-feminist cynics and so on. What is of interest in the context of this study 
is the total failure of family for nearly all the women. One does have an understanding husband, but his task is merely to keep her psychosis under control with nurses and drugs (82-4). Jaya Singh, Delhi socialite, resigns herself to her fate to maintain material comfort within a marital relationship that includes her abuser as her husband's friend (55-61). The young Tara has been used as surrogate wife by her widower father and is totally cynical about all relationships (84-6). Maya's husband “flogs" her, verbally if not also physically (43), Anahita's instantly divorces her (78). Maya's childhood is marred by a mentally disturbed mother who never holds her (1415) and a cook who molests her at night (18). If this book has anything to do with the socialisation process, it must be read, like The God of Small Things, as a 'terrible example' of how dysfunctional families reproduce themselves with minor differences across generations. Like Anahita, Maya's support comes from old friends such as Ket, and from children. They are the break in the chain of family tyranny. Another means of resocialisation for Maya (though in her case it ambiguously perpetuates some aspects of her neurosis) is the comfort of religious yearning.

Anupa Mehta's 'new age' spiritualism is a substitute mode of belonging that replaces her character's quest for alternative family via unhelpful bonding with a psychologist. One hesitates to read too much into this book, but Maya's name and the recurrent figure of the ideal Beloved, Mir, suggests the longevity of the bhakti/sufi poetic conceit that we find earlier in Kamala Das's poetry of female anguish. Paradoxically, the Hindu concepts and practices that tie the woman to either a secure or a stultifying domestic life also provide the models for female liberation in Bhakti figures such as Mira Bai, and in transcendental symbols of fulfilled desire as in the Radha-Krishna relationship. Das flees a traumatic induction to marriage and subsequent neglect by 
her husband, then faces the melancholy aftermath of affairs. The bitter burning away of desire through physical indulgence is counterpointed with the unending hope of a fulfilling relationship in which the individual is sublimated into the ideal half of a spiritualised love figured as Radha-Krishna. We can note that such a personal consolation of non-carnal emotional union is adopted by women who are resolutely presenting as modern and who inhabit a world of cities. Anupa Mehta's characters all move around into and out of Bombay, and Das was removed from her Kerala origins to spend most of her creative life in Calcutta and Delhi. Poetic religion in such a context offers a way to transcend disruptions of time and space, the weaknesses of personality, and to find belonging and identity in cultural tradition. So when Priti in Gurcharan Das's A Fine Family seeks to resolve an inner restlessness that neither life experience, city living, nor marriage can assuage, she turns to the guru her father-inlaw has followed and retreats to his ashram. This particular guru is a modern thinker of multi-faith sympathies (148) and Nehruvian practicalities, combining meditation with hard labour to promote a green revolution in the Punjab (292). The novel approves of him because his way is compatible with its secular, humanist and democratic ideals. Such ideals, however, begin to displace the consolations of religion for the next generation, if we believe all the popular fiction of the 'chick lit' and 'IT lit' kind. (Again, Chetan Bhagat's book is almost entirely secular apart from the author's use of the divine as a self-aware narrative trick.) In the more literary work of Siddharth Dhanvant Shangvi, too, family for the younger Bombayite seems to be friends or nothing, and though The Lost Flamingoes of Bombay is haunted by longing, religion is not available as surrogate family, nor is education a bulwark against misfortune or disappointment. 
The other option available to contemporary Indians is migration. Again, this is something a family may do to enhance its place in the world, either in terms of furthering education and career or making strategic marriages for children. But in the very act of 'going global' the family threatens itself with fragmentation, and its individual members may face as much anomie as excitement. We have only to think of Jhumpa Lahiri's work and the break in communication in The Namesake that causes Gogol/ Nikhil to wander rather aimlessly around in search of an identity to see the cost to family and selfhood quite apart from any hostility towards the migrant from host populations. If there is a home-grown element of existentialist alienation, from Anita Desai and Arun Joshi, through to Upamanyu Chatterjee, in which family ceases to provide sustaining bonds, it is complemented, perhaps magnified, by diasporic writing (the central character in Red Earth Pouring Rain, for example, is aimless in America and bored back home until the fantastic erupts into his world and he is progressively reinserted into his family, culture and community.

When societies begin to pluralise and cross into transnational networks, the comfortable structures of class and family being to take on new, flexible forms and there is often a political division into those benefiting from and celebrating the change, and those crying for a return to/ preservation of 'family values'. Fiction can, wittingly or not, dramatise the splits, anxieties and freedoms of such transition. Before he ceased being the globetrotting NRI, Shashi Tharoor mounted an apparently postmodern but basically liberal critique of Hindu fundamentalist sectariansim in his fictionalisation of communal violence. Riot deals with the hindutva idea of nation as close-knit cultural family crossing with nation as multicultural space to produce communal warfare akin to inter-family vendetta. There is little doubt that it scorns the 
self-seeking petit-bourgeois town politician who manipulates cultural differences to create a platform for his own career, but the characters set up as maintaining the state's authority are at best compromised by cynicism (in the figure of a foul-mouthed hard-drinking Sikh police officer) and moral laxity (in the central male character, Lakshman, the District Magistrate). The political events in Zalilgarh that result in riot and the seemingly related death of an American aid-worker, are framed by a 'backstory' that charts how a dysfunctional foreign family indirectly comes to threaten the stability of the Indian governing class, and the novel ends with the secularised district magistrate closing down his 'modern' affair and suppressing the full story of his lover's death. Although shot through with ironies, such as the devout wife of the magistrate playing a part in the tragic denouement, the story's resolution seems to affirm traditional ideas about the sanctity of 'family values' which rest on stereotypic views of higher philosophical Hindu beliefs that the rest of the book seems to question.

A similar anxiety about letting go of old family structures can be found more overtly in Bharati Mukherjee's Desirable Daughters. It is more apparent because the writer sets forth her own expatriation as the basis for a fictional quest for personal and family identity in Tara, a modern Indian divorcee resident in the US. Mukherjee has celebrated the American idea of the melting pot, the adventure of migrant selftransformation through which American society is also transformed (“American Dreamer"). Tara who continually takes on new personae, mocks her sister's 'ethnic exploitationism' in becoming a representative Indian media personality amongst the diasporic ghetto of Queens in New York, and criticises the barren lifestyle of Mumbai elite couples as represented by her other sister, but ultimately reconnects with them 
and with their parents' and grandparents' family story. That story is also part of the Indian national story and is itself subject to constant renewal and change, but the final vision of the novel seems to be an essentially conservative one, and the protagonist is reunited with her 'proper' Indian husband, and both are reconciled with their gay son. Like some of the other books mentioned, traditional religious belief supplies the current that carries disparate elements towards a relatively harmonious ending. The Indian family can undergo all kinds of changes but will accommodate them and spread to encompass the world. The same message comes through in the more popular American novel of diasporic family life, Serving Crazy with Curry. This does not require reconnection with the homeland or even any mode of religious belief. Three generations are now resident in the one place in the US, all raised in professions such as medicine and the army, then IT and journalism, and all work out their personal angsts with and against each other in a commendably reasoned way, albeit with dramatic outbursts of passion and the help of some therapeutic cooking (complete with recipes).

Most of the books mentioned so far, whether at home or (at home) abroad, share one thing: class. As Mistry's A Fine Balance points out, belonging to a rich family, however oppressive that can be, provides more protection against the machineries of fate than even education. Coming to a big city as a lowly village artisan, on the other hand, for all the opportunities a city can offer, can end up in disaster and street beggary. Migrating overseas to the bright lights of America can be a happy experience for the professional, but it can also result in the sweated labour, crowded slum accommodation and uncertain fate of someone like poor Biju in Kiran Desai's The Inheritance of Loss. In Rupa Bajwa's The Sari Shop, the orphan Ramchand 
survives so long as he allies himself with his surrogate family of the shop workers. He learns this when he witnesses drunkenness and death in a colleague's family because they lose employment. Class difference is highlighted by Bajwa when she has Ramchand selling saris to the rich, giving him dreams above his station without any sense of their effect on him. The same kind of class contrast produces rather more self-questioning for the middle-class protagonist in Shashi Deshpande's The Binding Vine, in which she is confronted with helping to care for the raped daughter of a neighbour. In line with these books, Thrity Umrigar tracks the relentless fall in the fortunes of Bhima and her granddaughter, contrasting and connecting this to the impervious comfort of a rich Parsi family in Mumbai.

The Space Between Us shuttles back and forth in time and to and fro between employer Sera Dubash and servant Bhima. They are friends of a kind, since Bhima has comforted Sera during years of marriage in which she has been tormented by a manipulative, possibly deranged, mother-in-law and beaten by her outwardly charming husband. (The book shows the distorting effect of traditional socialisation of boys, where they stay spoiled by and tied to their mother to the point of being blind to their wives' torment after they marry or violent towards them when they complain.) Bhima has also helped raise Sera's daughter, Dinaz, now married to Viraf and expecting a baby. The Dubashes are criticised by their social circle for being too generous to Bhima. Sera is flexible about her punctuality and the family provide support for her husband when he is hospitalised after an industrial accident and then for her granddaughter's education. Bhima's husband has taken to drink and deserted her, and her daughter has died of AIDS contracted from marrying an unknowing 
carrier who also dies. Bhima and Maya are forced to live in a slum hut, and now Maya, at sixteen, is pregnant and sullen.

The book captures well the mixed gratitude and resentment felt by the now sixty-five year-old woman towards her benefactors. She knows that their kindness is mixed with arrogance and carelessness and self interest, just as her friendship with Sera is marked by different cups and different seating arrangements when they share a tea-break. Dinaz's outspoken championing of the rights of the poor to respect and fair play comes from the privilege of being able to be charitable without any real cost. The Dubashes arrange an abortion for the grand-daughter without really consulting either Bhima or Maya herself. It is as though 'the family' asserts its rights over all individuals attached to it. But when Bhima reveals that Maya's pregnancy is due to Viraf's seducing her, the one extended family suddenly becomes two families; the rich close ranks, Viraf frames Bhima in petty theft, and they dismiss her with accusations of ingratitude. We are left with two distinct kinds of family dysfunction: one a tragic decline into destitution; the other a stasis of hypocrisy resting on privilege of class, education, wealth and, in this case, ethnic enclosure. This is not the urban liberation of Arjun's Bombay in A Fine Family: it is closer to the mixed fortunes and messy lives in A Fine Balance. What unifies the two classes, though, is a common insistence on education as the way up in society. This is not just a reflection of the Parsi ethos; Hindu peasant Bhima is determined that somehow she will keep Maya at school so she will not have to share her own fate. Religion seems not to feature as any more than neurotic fixation on ritual amongst the older Parsi women, or indifference on Bhima's part. Consolation comes from Umrigar choosing a more formula approach than Mistry. This includes clinging to an improbably hopeful ending for 
Bhima that owes something to the sentimentality of Tagore's "Cabuliwallah", but her book is nonetheless another story of the modern urban family under stress.

Pranav Jani observes that "In literary analysis, positing the nation as being always already inimical to women's progress and liberation sets up a false dichotomy in which nation-oriented writing is regarded as necessarily uncritical of women's oppression while texts that challenge gender norms are inevitably anti- or postnational" (104). This can be argued, but certainly some of the more recent crop of 'women's' novels (such as Manju Kapur's Home) tend to centre on individual and family as though politics of nation and state are extraneous. The link in all this is the concept of nation as family and India as Mother, and Gurcharan Das's A Fine Family maps the progress of its characters against the historical emergence of an independent nation, matching family crisis with Indira's suspension of regular political process, as does Rohinton Mistry's A Fine Balance.

Woman-centred writing that exposes the inherent violence in traditional patriarchal families (often proxy-managed by oppressive mothers-in-law) may seem to put aside inspection of the national family (Githa Hariharan and Shashi Deshpande come to mind as well as Anita Desai), but their work is in part a statement that the personal is the political, the family is the nation, rather than the reverse (a point made clear in Difficult Daughters and HomeSpun). But exposing disruption and dysfunction in one can require contrastive distinction between the two. The nation may need to remain an ideal guaranteeing the rights of citizens so that individuals can claim justice within families. Or families may need to remain the source of belonging, harmony and identity to compensate for the inadequacies of the modern state. The White Tiger 
takes the extreme position where state and family are both corrupt and each is so bound up with the other that both are rejected in a radical act of self-definition as defection and alienation.

Balram is beset by two families: his birth family, run by a venal and cunning grandmother, and his employer's family, urban businessmen involved in national politics who are also the rural overlords of his grandmother's village. For a while, the latter provide him with a means of survival and a kind of education when he escapes to Delhi, but between them and his birth family, he is going to be kept poor and in service, wherever he lives. His families socialise him to be a blindly compliant rooster in a crowded rooster coop. This is not unlike the situation in The God of Small Things where we see a vicious family enclave of domestic violence, sexual exploitation of female workers, and oppression of divorcees so mixed in with communal prejudices, caste discrimination, state politics and global economics, that there seems to be no escape.

Balram's solution is to reject both families. He is able to do this because people from the edge and outside of each group (an inspector visiting his village school, the bus conductor who can 'see the world', then a US-educated son returning to his zamindari clan with his westernised wife) give him the ability to see his situation, until he himself moves to the edge and, in correspondence with the Chinese Premier, can comment disparagingly on his national 'family' as well. His position parallels the love-hate relation of Adiga as returned expatriate with his strange/ familiar nation/ family. Balram ironically ends up as ruthless and corrupt as those he criticises. If he kills off his links with the family of mafia-like feudal India to become a rootless 
entrepreneur in a new city of migrants from everywhere else, he 'speaks the same language as the Thakurs and the politicians — money — and he begins to construct a new family for himself. His workers become his children; he becomes the local power-broker and consoler of the hurt. And although he remains isolated from social contacts in his chandelier-lit bunker with money as the only glue holding his 'family' together, he has kept his nephew with him and is, in good middle-class aspirational mode, trying to get the boy a good education. Balram's secessionist national family of one is already assuming the form of India's modern technocratic and capitalist family.

So although the early alliance in fiction between family, culture and nation noted by Mukherjee is seen to break open as the nation itself undergoes change, with increased emphasis on the individual in urban, commercial and diasporic contexts, this is not altogether a single narrative of progress away from the family as a central concern in Indian English fiction. Some elements (such as the importance of the mother/ motherin-law/ matriarch) remain important. Attitudes to the overall shift vary from nostalgic reconstructions of old communal ideals to satiric exposés of realities behind them, from celebrations of individual liberty to laments about the alienation that can go with such freedom. Given the position of the writer in English, it is hardly surprising that the modern independent, educated individual is consistently the focus around which our sympathies are orchestrated, but somehow or other, it is a form of family, whether relatives, colleagues or religious communion that is recuperated as a site in which meaning or solace can be found when the contemporary nation or modern globalised society can no longer be equated with the family.

\section{Bibliography}

Adiga, Aravind. The White Tiger, London: Atlantic Books, 2008.

Bajaj, Karan. Keep off the Grass. Noida: Harper Collins, 2008.

Baker, David. "St. Stephens College, Delhi, 1881-1997: An 'Alexandria on the banks of the Jamuna'?" Knowledge, Power \& Politics: Educational Institutions in India. (ed. Mushirul Hassan) New Delhi: Lotus/Roli, 1998: 66-113.

Bhagat, Chetan. one night @ the call center New Delhi, Rupa, 2005.

Bhagat, R.B. "Urbanisation in India: A Demographic Reappraisal" http://www.iussp.org/Brazil2001/s80/S83_03_Bhagat.pdf Accessed 6-12-2011.

Bajwa, Rupa. The Sari Shop, New Delhi: Penguin, 2004.

Chand. Prem. Deliverance and Other Stories. (trans. David Rubin). New Delhi: Penguin, 1988.

Chandra, Vikram. Red Earth and Pouring Rain, London: Faber \& Faber, 1995.

- Love and Longing in Bombay, London: Faber \& Faber, 1998.

- Sacred Games, London: Faber \& Faber, 2006. 
Chatterjee, Upamanyu. English, August. Calcutta: Rupa, 1988.

Chauhan, Chetan. "Urbanisation in Inida faster than rest of world" Hindustan Times 27 June 2007. http://www.hindustantimes.com/News-Feed/India/Urbanisation-inIndia-faster-than-restof-the-world/Article1-233279.aspx Accessed 6-12-2011.

Das, Gurcharan. A Fine Family. New Delhi, Penguin, 1990.

Das, Kamala. Summer in Calcutta. New Delhi: Rajinder Paul, 1965.

—. The Old Playhouse and other Poems. Madras: Orient Longman, 1973.

Desai, Anita. Fire on the Mountain. Harmondsworth: Penguin, 1981.

Desai, Kiran. The Inheritance of Loss. London: Penguin, 2006.

Deshpande, Shashi. The Dark Holds no Terrors. New Delhi: Vikas, 1980.

—. That Long Silence. London: Virago, 1988.

-. The Binding Vine. New York: The Feminist Press CUNY, 2001.

Gokhale, Namita. The Book of Shadows. New Delhi: Penguin, 2001.

Gupta, Narayani \& Sheila Uttam Singh. "The Interior and the Exterior: Indraprastha College for Women" Knowledge, Power \& Politics: Educational Institutions in India. (ed Mushirul Hassan) New Delhi: Lotus/Roli, 1998: 141-155.

Hariharan. Githa. The Thousand Faces of Night. Harmondsowrth: Penguin, 1992.

Jani, Pranav. Decentering Rushdie: Cosmopolitanism and the Indian Novel in English. Columbus: Ohio State UP, 2010.

Jha, Raj Kamal. The Blue Bedspread. London: Picador, 1999.

Kakar, Sudhir. The Inner World: A Psychoanalytic Study of Childhood and Society in India. $2^{\text {nd }}$ edition. Delhi: Oxford UP, 1981.

Kapur, Manju. Difficult Daughters. New Delhi: Penguin, 1998.

-. Home. New Delhi: Random House. 2006.

Lahiri, Jhumpa. Namesake. London: Harper, 2004.

Lokugé, Chandani. (ed.) Saguna: The First Autobiographical Novel Written in English by an Indian Woman. New Delhi: Oxford University Press, 1998.

-. (ed.) India Calling, The Memories of Cornelia Sorabji, India's First Woman Barrister. New Delhi: Oxford University Press, 2001.

-. (ed.) Ratanbai: A High-Caste Hindu Child-Wife, New Delhi: Oxford University Press, 2004.

Malladi, Amulya. Serving Crazy with Curry. London: Piatkus, 2004.

Mehta, Anupa. The Waiting Room. New Delhi: Penguin, 2007.

Mistry, Rohinton. A Fine Balance, London: Faber \& Faber, 1995.

Mukherjee, Bharati. Desirable Daughters. Crows Nest, Sydney: Allen \& Unwin, 2002.

Mukherjee, Meenakshi, Realism and Reality: The Novel and Society in India, Delhi: Oxford University Press, 1985.

Narayan, R.K. The Vendor of Sweets, Harmondsworth: Penguin, 1983.

Rang de Basanti, Dir. Rakyesh Omprakash Mehra, UTV, 2006.

Roy, Arundhati. The God of Small Things, London: Flamingo, 1997.

Sahgal, Nayantara. Rich Like Us. London: Heinemann, 1985.

Shanghvi, Siddharth Dhanvant. The Lost Flamingoes of Bombay, New Delhi: Viking/ Penguin, 2009.

Sharma, Akhil. An Obedient Father, London: Faber \& Faber, 2001.

Swarup, Vikas. Slumdog Millionaire. London: Doubleday, 2005, Black Swan 2006.

—. Six Suspects, London: Doubleday, 2008; Black Swan, 2009.

Tagore, Rabindranath. Collected Stories. Delhi: Macmillan, 1974.

Tharoor, Shashi. Riot, New Delhi: Viking/Penguin, 2001.

Umrigar, Thrity. The Space Between Us New Delhi: Harper Collins, 2006. 
Vachani, Nilita. HomeSpun, New Delhi: Penguin India, 2005. 